\title{
FAKTOR-FAKTOR YANG MEMPENGARUHI PEMILIHAN KARIR MAHASISWA S1 AKUNTANSI SEBAGAI AKUNTAN PUBLIK
}

\author{
Vania Susanto ${ }^{1}$, Jeremy Everrell ${ }^{2}$, Nany Chandra Marsetio ${ }^{3}$, Achmad Setyo Hadi ${ }^{4}$ \\ 1,2,3,4Sekolah Bisnis dan Ekonomi, Universitas Prasetiya Mulya, Tanggerang, Indonesia \\ Email Korespondensi: vania.susanto@student.pmsbe.ac.id
}

\begin{abstract}
This research aims to examine the effect of compensation, variety of work experiences, marketability, high turnover, work environment, subjective norms, difficulty to pursue CPA certification, intention to pursue CPA certification, extensive travel and internship experiences on the career choice of undergraduate accounting students as public accountants using theory of planned behavior and motivation theory. The sample was collected by using purposive sampling, resulting in 155 undergraduate students from 3 private universities and 3 public universities in Java Island. Logistic regression analysis is used with the help of SPSS 26. Interviews as a triangulation is conducted to understand the results better. Results show that compensation, subjective norms and intention to pursue CPA certification have a positive influence while high turnover and extensive travel have a negative influence on the career choice of undergraduate accounting students as public accountants. The results of logistic regression also found that variety of work experiences, marketability, work environment, difficulty to pursue CPA certification and internship experiences have no influence on the career choice as a public accountant. This paper has important implications as a reference for future research, for the preparation of the accounting study program curriculum, as interview materials for the recruitment process, and for IAPI to socialize the CPA certification requirements.
\end{abstract}

Keywords: Career Choice, Public Accountant, Behavior, Motivation

Abstrak: Penelitian ini bertujuan untuk menguji pengaruh kompensasi, keberagaman pengalaman kerja, marketability, turnover yang tinggi, lingkungan kerja, subjective norms, kesulitan memperoleh sertifikasi CPA, rencana mengambil sertifikasi CPA, travel berlebihan, dan pengalaman magang terhadap pemilihan karir mahasiswa S1 akuntansi sebagai akuntan publik dengan pendekatan teori perilaku yang direncanakan dan teori motivasi. Pengambilan sampel menggunakan purposive sampling yang menghasilkan 155 mahasiswa jurusan akuntansi dari 3 universitas swasta dan 3 universitas negeri di Pulau Jawa. Analisis regresi logistik dilakukan dengan program SPSS 26. Triangulasi wawancara dilakukan untuk memahami lebih dalam hasil penelitian. Hasil penelitian menunjukkan bahwa kompensasi, subjective norms, dan rencana mengambil sertifikasi CPA berpengaruh positif sedangkan turnover yang tinggi dan travel berlebihan berpengaruh negatif terhadap pemilihan karir mahasiswa akuntansi sebagai akuntan publik. Dari hasil regresi logistik juga ditemukan bahwa keberagaman pengalaman kerja, marketability, lingkungan kerja, kesulitan memperoleh sertifikasi CPA, dan pengalaman magang tidak berpengaruh terhadap pemilihan karir sebagai akuntan publik. Implikasi Implikasi penelitian ini berguna sebagai referensi untuk penelitian selanjutnya, untuk penyusunan kurikulum program studi akuntansi, bahan interview dalam proses rekrutmen, dan masukan untuk IAPI untuk sosialisasi persyaratan sertifikasi CPA.

Kata Kunci: Pemilihan Karir, Akuntan Publik, Perilaku, Motivasi 


\section{PENDAHULUAN}

Indonesia menghasilkan 35.000 lulusan akuntansi setiap tahunnya yang merupakan jumlah terbanyak di ASEAN (Siaran Pers IAI 2015). Namun, data IAPI (Institut Akuntan Publik Indonesia) per 31 Januari 2020 menunjukkan bahwa jumlah akuntan publik di Indonesia sampai tahun 2020 hanya sebesar 4.226 orang. Hasil dari survei tersebut membuktikan bahwa secara signifikan jumlah lulusan akuntansi yang memilih berprofesi sebagai akuntan publik tidaklah banyak. Perbandingan yang jauh ini menunjukkan bahwa tidak banyak lulusan akuntansi yang memilih berkarir sebagai akuntan publik. Padahal profesi akuntan publik merupakan profesi yang salah satunya tugasnya adalah memberikan opini kewajaran laporan keuangan untuk Perusahaan Terbuka, persero, perusahaan dengan aset Rp 50 M (UU No. 40 Tahun 2019). Saat ini, Indonesia memiliki sekitar 700.000 perusahaan, namun baru 30.000 perusahaan yang menggunakan jasa Akuntan Publik (SPT Badan tahun 2019). Kekurangan akuntan publik dapat menjadi ancaman bagi perusahaan yang membutuhkan jasa dari seorang akuntan publik, terutama untuk perusahaan yang laporan keuangannya wajib diaudit. Sehingga, penting bagi perekrut untuk mengetahui faktor apa saja yang berpengaruh dalam pemilihan karir sehingga dapat menarik lulusan akuntansi untuk bekerja sebagai akuntan publik.

Penelitian mengenai faktor yang mempengaruhi pemilihan karir sebagai akuntan publik telah dilakukan di berbagai negara, termasuk Cina, Malaysia, dan Amerika Serikat dengan berbagai faktor yang berbeda-beda, seperti penghargaan finansial, lingkungan kerja, norma subjektif, pengalaman magang dan sebagainya. Penelitian sebelumnya menghasilkan temuan yang berbeda pula (Bagley et al., 2012; Edward Beck \& Halim, 2008; Hermanson et al.1995; Nouri et al., 2005; Law, 2010; Omar et al., 2015). Di Indonesia, sudah ada beberapa penelitian mengenai isu yang sama (Ambari \& Ramantha, 2017; Crisostomo, 2015; Dary \& Ilyas, 2017; Merdekawati \& Sulistyawati, 2011; Saputra, 2018; Sari, 2013; Solikhah, 2014) namun belum ada penelitian mengenai semua variabel yang digunakan dalam penelitian Wen et al. (2018). Hal ini merupakan ruang penelitian untuk mereplikasi penelitian Wen et al. (2018) tentang faktor-faktor yang mempengaruhi pemilihan karir mahasiswa akuntansi di Cina sebagai akuntan publik. Selain itu, penelitian ini juga menambahkan pengalaman magang sebagai salah satu faktor yang mempengaruhi pemilihan karir seseorang (Ahmad et al., 2015) dengan lebih berfokus pada mahasiswa S1 akuntansi.

Sehingga penelitian ini bertujuan untuk menguji pengaruh kompensasi, keberagaman pengalaman kerja, marketability, turnover yang tinggi, lingkungan kerja, subjective norms, kesulitan memperoleh sertifikasi CPA, rencana mengambil sertifikasi CPA, travel berlebihan, dan pengalaman magang pada pemilihan karir mahasiswa S1 akuntansi sebagai akuntan publik dengan pendekatan teori perilaku yang direncanakan atau theory of planned behavior (TPB) dan teori motivasi. Penelitian ini ingin melihat apakah attitudes towards behavior, subjective norms, dan perceived behavioral control mempengaruhi terbentuknya perilaku pemilihan karir mahasiswa S1 akuntansi serta apakah faktor motivasi dan faktor murni mempengaruhi seseorang dalam memilih karir. Diharapkan hasil dari penelitian ini dapat berkontribusi dalam melengkapi penelitianpenelitian sebelumnya mengenai faktor-faktor yang mempengaruhi pemilihan karir mahasiswa akuntansi, membantu perguruan tinggi dalam penyusunan kurikulum bagi 
mahasiswa S1 jurusan akuntansi, sebagai masukan untuk Kantor Akuntan Publik (KAP) yang ingin merekrut akuntan publik, dan sebagai salah satu sumber referensi bagi penelitian selanjutnya yang ingin meneliti topik yang sama.

\section{TINJAUAN PUSTAKA}

\subsection{Theory of Planned Behavior}

Setiap individu memiliki perilakunya masing - masing yang dipengaruhi oleh banyak faktor. Keberagaman perilaku membuat para ahli melakukan penelitian untuk menjelaskan pendapat mereka mengenai faktor apa saja yang dapat mempengaruhi terbentuknya sebuah perilaku pada seorang individu. Menurut Teori Tindakan Beralasan (Theory of Reasoned Action) oleh Ajzen dan Fishbein (1980) mengatakan bahwa keinginan individu untuk melakukan suatu perilaku adalah asal dari sebuah perilaku yang terbentuk. Kemudian teori ini dikembangkan oleh Ajzen (1991) dengan nama Teori Perilaku yang Direncanakan (Theory of Planned Behaviour atau TPB). Ajzen (1991) menambahkan persepsi perilaku kontrol sebagai faktor yang mempengaruhi keinginan dan juga perilaku seseorang. Maka TPB memiliki 3 variabel yang mempengaruhi seseorang dalam berperilaku, yaitu: Attitudes towards Behavior mengacu pada penilaian terhadap sebuah perilaku oleh individu. Dalam penelitian ini, sikap terhadap perilaku adalah persepsi mahasiswa akuntansi terhadap profesi akuntan publik. Subjective Norms mengacu pada tekanan sosial yang dirasakan untuk melakukan atau tidak melakukan sebuah perilaku. Kepercayaan normatif mempengaruhi subjective norms seorang individu dalam berperilaku. Dalam penelitian ini, subjective norms dilihat dari pandangan dan dorongan orang sekitar, seperti, keluarga, teman, dosen, dan sebagainya pada pemilihan karir sebagai akuntan publik. Perceived Behavioral Control merupakan variabel yang memiliki pengaruh terhadap keinginan dan juga perilaku. Faktor ini mengacu pada bagaimana seorang individu percaya memiliki atau tidak memiliki kemampuan untuk melakukan sebuah perilaku. Dalam penelitian ini, kontrol perilaku mengacu pada kesulitan atau kemudahan yang dirasakan oleh mahasiswa akuntansi dalam berkarir sebagai akuntan publik.

\subsection{Teori Motivasi}

Teori dua faktor (Two-Factor Theory) merupakan teori motivasi yang dikembang oleh Frederick Herzberg yang juga dikenal sebagai motivation-hygiene theory yang menciptakan paradigma dua dimensi tentang faktor-faktor yang mempengaruhi sikap seseorang terhadap pekerjaan. Herzberg et al. (1959) bersama rekannya mengembangkan sebuah teori yang menjelaskan bahwa kepuasan dan ketidakpuasan merupakan hal yang berbeda sehingga tidak dapat diukur pada kontinum yang sama. Teori dua faktor dibagi menjadi 2, yaitu faktor motivasi (intrinsik) dan faktor murni (ekstrinsik).

Faktor motivasi atau disebut sebagai 'satisfier' bekerja untuk meningkatkan dan mengembangkan kepuasan kerja. Faktor motivasi meliputi pencapaian, pengakuan (verbal), pekerjaan yang menantang, peningkatan dan pertumbuhan dalam pekerjaan (Herzberg, 1966, 2003). Faktor murni, berperan sebagai faktor ekstrinsik pada pekerjaan. Faktor murni atau juga disebut sebagai 'dissatisfier' berkaitan dengan kebutuhan untuk menghindari ketidakpuasan (Herzberg et al., 1959). Faktor murni meliputi kebijakan dan administrasi perusahaan, hubungan antara individu, pengawasan (kualitas teknis), 
kondisi kerja fisik, keamanan bekerja, tunjangan, dan gaji (Herzberg, 1966; Herzberg, 2003).

\subsection{Profesi Akuntan Publik}

Akuntan publik adalah seseorang yang telah mendapatkan izin untuk memberikan jasa audit dan reviu atas informasi keuangan historis, jasa asurans lainnya, serta jasa lainnya terkait dengan akuntansi, keuangan, dan manajemen sesuai ketentuan perundang-undangan. Profesi ini tidak hanya diperuntukkan bagi lulusan akuntansi, namun lulusan non-akuntansi juga memiliki kesempatan asalkan telah lulus ujian sertifikasi menjadi akuntan publik. Izin menjadi akuntan publik diberikan oleh menteri dan berlaku selama 5 tahun sejak tanggal diberi izin dan dapat diperpanjang apabila masa berlaku izin telah berakhir. Namun, jika tidak diperpanjang maka akuntan publik tersebut tidak lagi menjadi akuntan publik. Akuntan publik memberikan jasanya melalui Kantor Akuntan Publik baik dalam bentuk perseorangan, persekutuan perdata, firma atau bentuk usaha lainnya yang sesuai dengan karakteristik profesi akuntan publik yang diatur dalam perundang-undangan.

\subsection{Pengembangan Hipotesis}

Kompensasi terhadap Pemilihan Karir

Penelitian-penelitian ini menunjukkan bahwa tidak ada hubungan yang signifikan antara faktor finansial atau penghargaan finansial dengan niat mahasiswa akuntansi dalam memilih akuntan publik sebagai karir (Dary \& Ilyas, 2017; Law, 2010; Merdekawati \& Sulistyawati, 2011; Wen et al., 2018). Namun, ada beberapa penelitian yang menunjukkan hasil yang berbeda. Hermanson et al. (1995), Ahmed et al. (1996), Sari (2013), dan Omar et al. (2015) menemukan imbalan finansial seperti gaji awal, potensi kenaikan gaji dan tersedianya dana pensiun merupakan faktor yang sangat penting dalam mempengaruhi mahasiswa akuntansi saat memilih preferensi pemilihan karir. Hipotesis pertama adalah:

H1: Kompensasi meningkatkan kecenderungan mahasiswa S1 Akuntansi dalam memilih karir sebagai akuntan publik.

\section{Keberagaman Pengalaman Kerja terhadap Pemilihan Karir}

Penelitian mengenai perilaku mahasiswa akuntansi dalam pemilihan karir yang didasarkan dengan teori TPB sudah dilakukan oleh para peneliti. Dari hasil penelitian yang telah dilakukan ditemukan bahwa pengalaman kerja yang bervariasi merupakan salah satu pengukuran dari pelatihan profesional (Sari, 2013). Pelatihan profesional tidak memiliki pengaruh terhadap pemilihan karir sebagai akuntan publik (Saputra, 2018). Sedangkan, penelitian lain menemukan bahwa pemilihan karir sebagai akuntan publik dipengaruhi oleh berbagai macam faktor salah satunya adalah akuntan publik merupakan pekerjaan yang bisa memberikan mereka keberagaman pengalaman kerja. Akuntan publik juga dapat memberikan kesempatan untuk bekerja di industri yang bervariasi (Bagley et al., 2012; Wen et al., 2018). Hipotesis kedua adalah:

H2: Keberagaman Pengalaman Kerja meningkatkan kecenderungan mahasiswa S1 Akuntansi dalam memilih karir sebagai akuntan publik.

Marketability terhadap Pemilihan Karir

Marketability merupakan kemampuan seseorang dalam mendapatkan peluang kerja yang diinginkan dari jenis perusahaan dan posisi yang diinginkan pada perusahaan lain 
di masa depan dengan kata lain sama halnya dengan pertimbangan pasar kerja. Dary \& Ilyas (2017) menemukan bahwa pertimbangan pasar kerja tidak mempengaruhi pemilihan karir mahasiswa akuntansi menjadi akuntan publik. Namun, ada penelitian yang menemukan bahwa hal ini memiliki pengaruh terhadap pemilihan karir oleh mahasiswa akuntansi sebagai akuntan publik dengan persepsi profesi akuntan publik memiliki prestise tinggi yang dapat memberikan peluang karir yang baik (Nouri \& Parker, 2013; Wen et al., 2018). Bekerja di KAP khususnya di Big 4 merupakan salah satu cara untuk mendapatkan prestise dan ini menjadi salah satu tujuan para pencari kerja untuk bekerja di KAP Big 4 menurut hasil survei yang dilakukan Bagley et al.(2012). Hipotesis ketiga adalah:

H3: Marketability meningkatkan kecenderungan mahasiswa S1 Akuntansi dalam memilih karir sebagai akuntan publik.

Turnover yang Tinggi terhadap Pemilihan Karir

Turnover yang tinggi berkaitan dengan ketidakstabilan Kantor Akuntan Publik yang ditunjukkan dengan frekuensi pergantian karyawan yang tinggi. Wen et al. (2018) menemukan bahwa turnover yang tinggi memiliki pengaruh negatif terhadap pemilihan karir mahasiswa akuntansi Cina sebagai akuntan publik. Mahasiswa akuntansi di Cina melihat adanya ketidakstabilan dalam bekerja sebagai akuntan publik. Perusahaan dengan employee turnover yang tinggi menyebabkan perusahaan mengalami kerugian di pasar tenaga kerja, dimana calon karyawan menjadi tidak tertarik untuk bekerja di perusahaan tersebut (Taylor \& Cosenza, 1998). Hipotesis keempat adalah:

H4: Turnover yang Tinggi menurunkan kecenderungan mahasiswa S1 Akuntansi dalam memilih karir sebagai akuntan publik.

\section{Lingkungan Kerja terhadap Pemilihan Karir}

Asmoro et al. (2015) dan Wen et al. (2018) menemukan bahwa lingkungan kerja yang dinamis dan apresiatif tidak berpengaruh atas pemilihan karir mahasiswa akuntansi menjadi akuntan publik. Namun, hasil yang berbeda ditemukan bahwa menemukan bahwa lingkungan kerja memiliki pengaruh signifikan dan positif ke pemilihan karir mahasiswa akuntansi menurut Ambari dan Ramantha (2017) dan Omar et al. (2015). Hipotesis kelima adalah:

H5: Lingkungan Kerja meningkatkan kecenderungan mahasiswa S1 Akuntansi dalam memilih karir sebagai akuntan publik.

Subjective norms terhadap Pemilihan Karir

Wen et al. (2018) menemukan bahwa pengaruh dari pihak luar, seperti keluarga, teman, profesor, dan akuntan profesional tidak berpengaruh terhadap pemilihan karir mahasiswa akuntansi Cina menjadi akuntan publik. Lukman dan Winata (2017) dan Ahmed et al. (1997) menemukan bahwa norma subjektif memiliki hubungan yang tidak signifikan terhadap pemilihan karir menjadi akuntan publik. Norma subjektif berhubungan dengan pengaruh orang sekitar yang sukses sebagai akuntan publik, anggapan dari teman, orang tua, dan dosen bahwa akuntan publik merupakan profesi yang prestise.

Sedangkan Bagley et al. (2012) menunjukkan bahwa norma subyektif berpengaruh signifikan dalam pemilihan karir mahasiswa akuntansi di Amerika Serikat sebagai akuntan publik di KAP Big 4. Pencari kerja cenderung mendapatkan tekanan sosial yang 
lebih tinggi untuk bekerja di KAP Big 4 dibanding KAP non-Big 4. Ada juga penelitian yang menemukan bahwa kelompok individu di sebuah lingkungan memiliki pengaruh atas pemilihan karir mahasiswa akuntansi menjadi akuntan publik (Dewi \& Budiasih, 2017; Solikhah, 2014; Law 2010). Hipotesis keenam adalah:

H6: Subjective Norms meningkatkan kecenderungan mahasiswa S1 Akuntansi dalam memilih karir sebagai akuntan publik.

Sertifikasi CPA terhadap Pemilihan Karir

Banyaknya syarat yang dibutuhkan seseorang untuk mengambil sertifikasi CPA di sebagian besar negara bagian Amerika Serikat membuat beberapa mahasiswa menghindari profesi akuntansi (Albrecht \& Sack, 2000). Wen et al. (2018) menemukan bahwa kesulitan dalam memperoleh kualifikasi profesional CPA memiliki pengaruh negatif sedangkan rencana untuk mengambil sertifikasi CPA memiliki pengaruh positif terhadap keputusan individu untuk berkarir di bidang akuntansi publik. Menurut Sun \& Zhang (2016) mahasiswa akuntansi di sekolah publik di Cina menganggap sertifikasi penting untuk pasar kerja. Ekspektasi yang akan didapatkan karena memiliki sertifikasi CPA adalah pendapatan yang lebih tinggi, keamanan kerja yang lebih baik, potensi kemajuan, peluang kerja yang lebih besar, serta penghargaan intrinsik. Semakin tinggi ekspektasi terhadap hasil yang akan didapatkan dari kepemilikan sertifikasi CPA, semakin tinggi pula minat mereka untuk memperoleh sertifikasi CPA (Gore \& Leuwerke, 2000). Hipotesis ketujuh dan kedelapan adalah:

H7: Kesulitan memperoleh sertifikasi CPA menurunkan kecenderungan mahasiswa S1 Akuntansi dalam memilih karir sebagai akuntan publik.

H8: Rencana untuk mengambil sertifikasi CPA meningkatkan kecenderungan mahasiswa S1 Akuntansi dalam memilih karir sebagai akuntan publik.

Travel Berlebihan terhadap Pemilihan Karir

Travel berlebihan yang harus dilakukan saat berprofesi akuntan publik memiliki efek negatif atas pemilihan karir mahasiswa akuntansi Cina menjadi akuntan publik (Nouri et al., 2005; Wen et al., 2018). Travel yang berlebihan ini berhubungan dengan kualitas family time karena dengan frekuensi bepergian yang tinggi ke luar daerah tempat tinggal akan mengurangi waktu bersama keluarga (Nouri et al., 2005). Hipotesis kesembilan adalah:

H9: Travel Berlebihan menurunkan kecenderungan mahasiswa S1 Akuntansi dalam memilih karir sebagai akuntan publik.

Pengalaman Magang terhadap Pemilihan Karir

Ahmad et al. (2015) menemukan bahwa pengalaman magang bukanlah faktor yang signifikan dalam mempengaruhi pemilihan karir mahasiswa akuntansi. Martin dan Wilkerson (2006) juga menemukan pengalaman magang tidak terlalu mempengaruhi ketertarikan dalam memilih karir di bidang akuntansi. Hal ini dikarenakan perusahaan tidak memberikan tugas yang berkaitan dengan akuntansi dan ketidakpuasan senior terhadap kinerja selama magang. Sedangkan Maelah et al. (2014) menemukan bahwa manfaat utama dari mengikuti program magang bagi mahasiswa akuntansi adalah untuk mendapatkan gambaran realita dunia kerja. Peningkatan pengetahuan yang relevan mengenai akuntansi merupakan manfaat yang didapatkan melalui program magang (Crisostomo, 2015). Pengalaman magang dapat membantu menentukan pemilihan karir 
di bidang akuntansi di masa depan serta mempersiapkan mahasiswa akuntansi untuk bekerja di bawah tekanan (Edward Beck \& Halim, 2008). Berdasarkan penjelasan mengenai berbagai pengalaman yang didapat dari program magang, hipotesis kesepuluh adalah:

H10: Pengalaman Magang meningkatkan kecenderungan mahasiswa S1 Akuntansi dalam memilih karir sebagai akuntan publik.

\section{Model Penelitian}

Berdasarkan telaah literatur dan pengembangan hipotesis di atas, maka kerangka penelitian ini dapat digambarkan sebagai berikut:

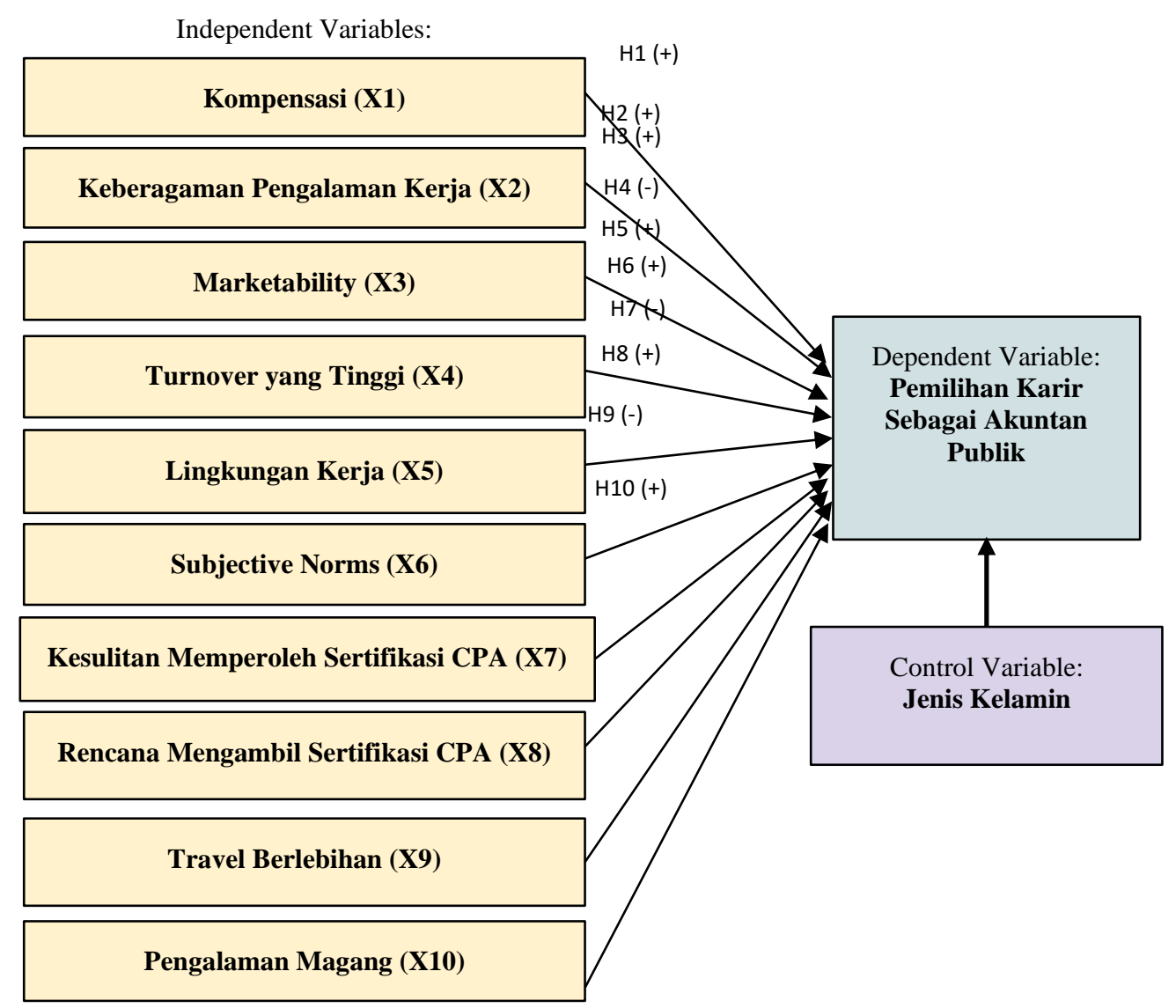

Gambar 1 Model Penelitian

\section{METODE PENELITIAN}

\subsection{Pengumpulan Data}

Penelitian ini menggunakan data primer yang diperoleh langsung dari objek penelitian dengan kuesioner. Kuesioner yang berisi daftar pertanyaan mengenai faktorfaktor yang dapat mempengaruhi pemilihan karir mahasiswa S1 Akuntansi akan disebar melalui online (Google Forms). Daftar pertanyaan tersebut diolah berdasarkan penelitian terdahulu yang ada di Tabel 1. Sebelum kuesioner disebarkan, pilot test (Denzin, 1970) dilakukan kepada 20 orang mahasiswa S1 akuntansi untuk memastikan masing-masing dari setiap responden memiliki pemahaman yang sama terhadap pertanyaan-pertanyaan 
yang diberikan (Polit et al., 2001). Setelah mendapatkan data dari kuesioner, akan dilakukan triangulasi dengan mewawancarai beberapa responden yang dianggap paling tepat untuk diwawancarai.

\subsection{Populasi dan Sampel}

Populasi yang digunakan pada penelitian ini adalah mahasiswa S1 program studi akuntansi di universitas swasta dan universitas negeri yang terletak di Pulau Jawa. Pemilihan sampel menggunakan teknik purposive sampling dengan beberapa kriteria, yaitu mahasiswa S1 jurusan akuntansi angkatan 2017 dan 2018 serta memiliki pengalaman magang di bidang akuntansi. Alasan dipilihnya mahasiswa angkatan 2017 dan 2018 sebagai sampel karena mereka telah memasuki tingkat akhir masa kuliah sehingga sudah memikirkan karir ke depan dan rata - rata telah memiliki pengalaman magang. Menurut Roscoe (dalam Sugiyono, 2017, p.156), jumlah sampel yang memadai untuk digunakan dalam penelitian adalah 30 sampai 500 orang. Sampel yang didapatkan untuk penelitian ini berjumlah 155 orang dari tiga universitas swasta dan 3 universitas negeri di Pulau Jawa, yaitu Universitas Katolik Parahyangan, Universitas Prasetiya Mulya, Universitas Bina Nusantara, Universitas Indonesia, Universitas Gadjah Mada and Universitas Jember.

\subsection{Operasionalisasi Variabel Penelitian}

Variabel dependen dalam penelitian ini merupakan variabel kualitatif yang berbentuk dummy, yaitu pemilihan karir sebagai akuntan publik yang dinilai dengan 1 jika memilih karir sebagai akuntan publik dan 0 jika memilih karir sebagai non-akuntan publik. Variabel kontrol yang digunakan dalam penelitian ini adalah jenis kelamin yang diberi nilai 1 jika merupakan perempuan dan 0 jika merupakan laki-laki. Variabel independen dari penelitian ini adalah kompensasi, keberagaman pengalaman kerja, marketability, turnover yang tinggi, lingkungan kerja, subjective norms, kesulitan memperoleh sertifikasi CPA, rencana mengambil sertifikasi CPA, travel berlebihan, dan pengalaman magang yang dikembangkan menjadi daftar pertanyaan yang ada di Lampiran 1 . Setiap pertanyaan dinilai dengan skala likert 5 poin, dimana 1 untuk sangat tidak setuju dan 5 untuk sangat setuju.

Tabel 1 Operasionalisasi Variabel Penelitian

\begin{tabular}{|c|c|c|}
\hline Variabel & Indikator & Referensi \\
\hline Dependen & \multirow{2}{*}{$\begin{array}{l}\text { 1. Menjadi akuntan publik (nilai 1) } \\
\text { 2. Menjadi non-akuntan publik (nilai 0) }\end{array}$} & \multirow{2}{*}{ Wen et al. (2018) } \\
\hline 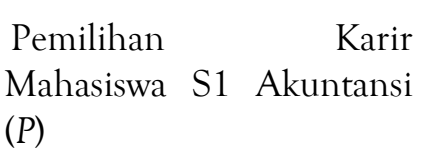 & & \\
\hline Independen & \multirow{2}{*}{$\begin{array}{l}\text { 1. Gaji awal yang tinggi. } \\
\text { 2. Potensi kenaikan gaji. }\end{array}$} & \multirow{2}{*}{$\begin{array}{l}\text { Omar et al. (2015), } \\
\text { Sari (2013) }\end{array}$} \\
\hline Kompensasi $\left(\mathrm{X}_{1}\right)$ & & \\
\hline $\begin{array}{c}\text { Keberagaman } \\
\text { Pengalaman Kerja }\left(\mathrm{X}_{2}\right)\end{array}$ & $\begin{array}{l}\text { 1. Banyak kesempatan untuk mendapatkan } \\
\text { berbagai pengalaman kerja. }\end{array}$ & $\begin{array}{l}\text { Bagley et al. (2012). } \\
\text { Wen et al. (2018), }\end{array}$ \\
\hline
\end{tabular}




\begin{tabular}{|c|c|c|}
\hline Variabel & Indikator & Referensi \\
\hline & $\begin{array}{l}\text { 2. Banyak kesempatan untuk mendapatkan } \\
\text { pengalaman kerja di industri yang } \\
\text { bervariasi. }\end{array}$ & \\
\hline Marketability $\left(\mathrm{X}_{3}\right)$ & $\begin{array}{l}\text { 1. Meningkatkan prestise diri di mata } \\
\text { masyarakat. } \\
\text { 2. Lebih banyak peluang untuk mendapatkan } \\
\text { posisi atau jabatan pekerjaan yang lebih } \\
\text { tinggi di masa depan. } \\
\text { 3. Lebih banyak peluang untuk mendapatkan } \\
\text { pekerjaan di masa depan. }\end{array}$ & $\begin{array}{l}\text { Nouri \& Parker } \\
\text { (2013), Wen et al. } \\
\text { (2018) }\end{array}$ \\
\hline Turnover yang tinggi $\left(\mathrm{X}_{4}\right)$ & $\begin{array}{l}\text { 1. Keinginan untuk keluar dari perusahaan } \\
\text { yang memiliki kohesivitas rendah } \\
\text { 2. Keinginan untuk keluar dari perusahaan } \\
\text { dengan turnover yang tinggi }\end{array}$ & Wen et al. (2018) \\
\hline Lingkungan Kerja $\left(\mathrm{X}_{5}\right)$ & $\begin{array}{l}\text { 1. Lingkungan kerja yang dinamis. } \\
\text { 2. Diberi apreasiasi apabila berprestasi. }\end{array}$ & Wen et al. (2018) \\
\hline Subjective Norms $\left(\mathrm{X}_{6}\right)$ & $\begin{array}{l}\text { 1. Anggapan dari teman bahwa Akuntan } \\
\text { Publik merupakan profesi yang prestise. } \\
\text { 2. Pengaruh orang sekitar yang sukses sebagai } \\
\text { Akuntan Publik. } \\
\text { 3. Tekanan dari orang tua. } \\
\text { 4. Rekomendasi dari dosen atau profesor. }\end{array}$ & $\begin{array}{l}\text { Bagley et al. (2012), } \\
\text { Lukman \& Winata } \\
\text { (2017), Wen et al. } \\
\text { (2018) }\end{array}$ \\
\hline $\begin{array}{l}\text { Kesulitan Memperoleh } \\
\text { sertifikasi CPA }\left(\mathrm{X}_{7}\right)\end{array}$ & $\begin{array}{l}\text { 1. Jangka waktu yang lama. } \\
\text { 2. Persyaratan yang banyak. }\end{array}$ & Wen et al. (2018) \\
\hline $\begin{array}{ll}\text { Rencana } & \text { mengambil } \\
\text { sertifikasi CPA } & \left(\mathrm{X}_{8}\right)\end{array}$ & $\begin{array}{l}\text { 1. Memiliki intensi mengambil sertifikasi } \\
\text { CPA. (nilai 1) } \\
\text { 2. Tidak memiliki intensi mengambil } \\
\text { sertifikasi CPA. (nilai 0) }\end{array}$ & Wen et al. (2018) \\
\hline Travel Berlebihan $\left(\mathrm{X}_{9}\right)$ & $\begin{array}{l}\text { 1. Waktu bersama dengan keluarga semakin } \\
\text { sedikit. }\end{array}$ & Nouri et al. (2005) \\
\hline Pengalaman Magang $\left(\mathrm{X}_{10}\right)$ & $\begin{array}{l}\text { 1. Mendapat gambaran realita dunia kerja. } \\
\text { 2. Memperoleh pengetahuan dan } \\
\text { keterampilan yang relevan dengan karir di } \\
\text { masa depan. } \\
\text { 3. Menjadi terbiasa dengan tekanan di dunia } \\
\text { kerja. }\end{array}$ & $\begin{array}{l}\text { Crisostomo (2015), } \\
\text { Edward Beck \& } \\
\text { Halim } \quad(2008) \text {, } \\
\text { Maelah et al. (2014) } \\
\text { - }\end{array}$ \\
\hline Control & \multirow{2}{*}{$\begin{array}{l}\text { 1. Perempuan (nilai 1) } \\
\text { 2. Laki-laki (nilai 0) }\end{array}$} & \multirow{2}{*}{ Wen et al. (2018) } \\
\hline Gender $\left(X_{11}\right)$ & & \\
\hline
\end{tabular}




\subsection{Metode Analisis Data}

Metode analisis yang dilakukan adalah analisis regresi logistik biner dengan bantuan program SPSS 26 untuk menguji probabilitas pemilihan karir mahasiswa S1 akuntansi sebagai akuntan publik. Penelitian ini menggunakan model penelitian sebagai berikut:

$$
\begin{aligned}
& \operatorname{Ln}\left[\left(\frac{p}{1-p}\right)\right]=\beta_{0}+\beta_{1} \mathrm{X}_{1}+\beta_{2} \mathrm{X}_{2}+\beta_{3} \mathrm{X}_{3}+\beta_{4} \mathrm{X}_{4}+\beta_{5} \mathrm{X}_{5}+\beta_{6} \mathrm{X}_{6}+\beta_{7} \mathrm{X}_{7}+\beta_{8} \mathrm{X}_{8}+ \\
& \beta_{9} \mathrm{X}_{9}+\beta_{10} \mathrm{X}_{10}+\beta_{11} \mathrm{X}_{11}+\mu
\end{aligned}
$$

Dimana:

$\mathrm{P}=$ probabilitas responden dengan pemilihan karir sebagai akuntan publik

$\mathrm{X} 1=$ kompensasi

$\mathrm{X} 2=$ keberagaman pengalaman kerja

$\mathrm{X} 3=$ marketability

$\mathrm{X} 4=$ turnover yang tinggi

$\mathrm{X} 5$ = lingkungan kerja

$\mathrm{X} 6=$ subjective norms

$\mathrm{X} 7=$ kesulitan memperoleh sertifikasi CPA

$\mathrm{X} 8=$ rencana untuk mengambil sertifikasi $\mathrm{CPA}$

$\mathrm{X} 9=$ travel berlebihan

$\mathrm{X} 10=$ pengalaman magang

$\mathrm{X} 11=$ jenis kelamin

$\beta 1-11=$ koefisien regresi

$\beta 0=$ konstantan (y-intercept)

$\mu=$ error

\section{HASIL DAN PEMBAHASAN}

\subsection{Statistik Deskriptif}

Dari 155 responden, jumlah mahasiswa perempuan $(73,5 \%)$ dalam penelitian ini lebih banyak dibandingkan mahasiswa laki-laki (26,5\%). Semua responden merupakan mahasiswa yang masih aktif berkuliah dari angkatan 2017 (61,3\%) dan 2018 (38,7\%) jurusan akuntansi. Sebagian besar dari responden $(98,1 \%)$ mengetahui mengenai profesi akuntan publik dan hanya sedikit dari mereka $(1,9 \%)$ yang tidak mengetahui mengenai profesi tersebut. Namun, hanya sebagian besar responden (67,1\%) memiliki minat menjadi akuntan publik sedangkan sisanya $(22,9 \%)$ tidak berminat. Minat menjadi akuntan publik terlihat lebih besar dari mahasiswa universitas swasta $(72,1 \%)$ dibandingkan universitas negeri $(27,9 \%)$ dari total 104 yang berminat. Hal ini mungkin dikarenakan jumlah responden dari universitas swasta dan negeri yang tidak seimbang. Banyak mahasiswa yang memiliki rencana untuk mengambil sertifikasi CPA $(61,3 \%)$ dan sebagian dari mereka $(38,7 \%)$ tidak ada rencana untuk memperoleh sertifikasi CPA.

Tabel 2 memperlihatkan statistik deskriptif dari 10 variabel independen di antara 104 mahasiswa yang ingin mempertimbangkan karir sebagai akuntan publik dan sisanya tidak ingin berkarir sebagai akuntan publik. Untuk yang variabel kompensasi $\mathrm{X}_{1}$ 
memiliki mean sebesar 8,20 bagi yang memiliki minat menjadi akuntan publik. Untuk yang tidak memiliki minat, rata-rata pada variabel $\mathrm{X}_{1}$ memiliki nilai yang lebih rendah yaitu 6,94. Mayoritas dari responden cukup setuju gaji awal yang tinggi dan potensi kenaikan gaji yang dapat diperoleh dari profesi sebagai akuntan publik.

Untuk variabel keberagaman pengalaman kerja $\mathrm{X}_{2}$ dengan rata-rata 8,77 dari responden yang memiliki minat menjadi akuntan publik. Terdapat perbedaan nilai ratarata untuk responden yang tidak minat pada item pertanyaan $\mathrm{X}_{2}$ menjadi sebesar 7,76 . Hal ini menunjukkan bahwa responden setuju bahwa keberagaman pengalaman kerja yang banyak bisa diperoleh saat berkarir sebagai akuntan publik.

Untuk variabel marketability $\mathrm{X}_{3}$ dengan rata-rata 12,81 dari responden yang memiliki minat menjadi akuntan publik. Terdapat perbedaan pada nilai rata-rata untuk responden yang tidak minat menjadi menjadi sebesar 11,16 . Hal ini menunjukkan bahwa dari kedua sisi responden cukup setuju bahwa marketability dapat diperoleh saat berkarir sebagai akuntan publik.

Untuk variabel turnover $\mathrm{X}_{4}$ dengan rata-rata 7,41 dari responden yang memiliki minat menjadi akuntan publik. Terdapat perbedaan nilai rata-rata untuk responden yang tidak minat pada $\mathrm{X}_{4}$. menjadi sebesar 7,37. Hal ini menunjukkan bahwa responden setuju bahwa turnover tinggi menjadi pertimbangan untuk berganti pekerjaan atau keluar dari perusahaan.

Untuk variabel lingkungan kerja $\mathrm{X}_{5}$ dengan rata-rata 8,67 dari responden yang memiliki minat menjadi akuntan publik. Terdapat perbedaan nilai rata-rata untuk responden yang tidak minat pada $\mathrm{X}_{4}$ yaitu sebesar 8,06 . Hal ini menunjukkan bahwa responden cukup setuju bahwa lingkungan kerja yang dinamis dan apresiatif bisa didapatkan saat bekerja sebagai akuntan publik.

Untuk variabel subjective norms $\mathrm{X}_{6}$ dengan rata-rata 13,64 dari responden yang memiliki minat menjadi akuntan publik. Terdapat perbedaan nilai rata-rata untuk responden yang tidak minat pada $\mathrm{X}_{6}$ yaitu sebesar 9,22. Dari kedua responden terlihat ada perbedaan signifikan dimana bagi mahasiswa yang berminat menjadi akuntan publik menunjukkan adanya pengaruh dari orang sekitar, sedangkan untuk yang tidak minat tidak merasa dipengaruhi oleh variabel tersebut.

Untuk variabel kesulitan memperoleh sertifikasi CPA $\mathrm{X}_{7}$ dengan rata-rata 7,38 dari responden yang memiliki minat menjadi akuntan publik. Terdapat perbedaan nilai ratarata untuk responden yang tidak minat pada $\mathrm{X}_{7}$ yaitu sebesar 6,92 . Hal ini menunjukkan bahwa dari dua sisi responden setuju dengan kesulitan untuk memperoleh sertifikasi CPA.

Untuk variabel travel berlebihan $\mathrm{X}_{9}$ dengan rata-rata 2,59 dari responden yang memiliki minat menjadi akuntan publik. Terdapat perbedaan nilai rata-rata untuk responden yang tidak minat pada $\mathrm{X}_{9}$ yaitu sebesar 2,94 . Hal ini menunjukkan bahwa responden dari sisi yang berminat menjadi akuntan publik lebih setuju bahwa travel berlebihan membuat mereka kesulitan dibanding responden yang tidak memiliki minat menjadi akuntan publik.

Untuk variabel pengalaman magang $\mathrm{X}_{10}$ dengan rata-rata 12,57 dari responden yang memiliki minat menjadi akuntan publik. Terdapat perbedaan nilai rata-rata untuk responden yang tidak minat pada $\mathrm{X}_{10}$ yaitu sebesar 12,31 . Hal ini menunjukkan bahwa 
160 Vania Susanto, Jeremy Everrell, Nany Chandra Marsetio dan Achmad Setyo Hadi

responden cukup setuju bahwa pengalaman magang dapat memberikan manfaat untuk karir di masa depan.

Tabel 2. Statistik Deskriptif

\begin{tabular}{|l|l|l|l|l|}
\hline & \multicolumn{2}{|c|}{ Minat } & \multicolumn{2}{c|}{ Tidak Minat } \\
\hline \multicolumn{1}{|c|}{ Item } & \multicolumn{1}{|c|}{$\mathrm{N}$} & \multicolumn{1}{c|}{ Mean } & \multicolumn{1}{c|}{$\mathrm{N}$} & \multicolumn{1}{c|}{ Mean } \\
\hline $\mathrm{X}_{1}$ & 104 & 8,20 & 51 & 6,94 \\
\hline $\mathrm{X}_{2}$ & 104 & 8,77 & 51 & 7,76 \\
\hline $\mathrm{X}_{3}$ & 104 & 12,81 & 51 & 11,16 \\
\hline $\mathrm{X}_{4}$ & 104 & 7,41 & 51 & 7,37 \\
\hline$X_{5}$ & 104 & 8,67 & 51 & 8,06 \\
\hline$X_{6}$ & 104 & 13,64 & 51 & 9,22 \\
\hline$X_{7}$ & 104 & 7,38 & 51 & 6,92 \\
\hline$X_{9}$ & 104 & 2,59 & 51 & 2,94 \\
\hline$X_{10}$ & 104 & 12,57 & 51 & 12,31 \\
\hline
\end{tabular}

Sumber: Hasil Olah Data SPSS V. 26, 2021

\section{Uji Validitas dan Uji Reliabilitas}

Uji validitas dapat dilihat dari menghubungkan dari setiap item pertanyaan terhadap skor total item yang memperlihatkan nilai signifikansi setiap item pertanyaan. Dilihat dari Tabel 3, dari semua item pertanyaan nilai signifikansi yang diperoleh kurang dari 0,05 dan koefisien korelasi bernilai positif. Dengan begitu dapat dikatakan setiap item pertanyaan valid dan dapat digunakan dalam penelitian ini. Pada uji reliabilitas, nilai Cronbach's alpha untuk semua item pertanyaan yang diperlihatkan berada di antara 0,70 $\leq \mathrm{r}_{11}<0,90$ dengan kategori reliabilitas tinggi. Hal ini menunjukkan pertanyaan setiap item reliabilitas tinggi dan sudah dapat digunakan dalam pengujian selanjutnya.

Tabel 3. Uji Validitas dan Uji Reliabilitas

\begin{tabular}{|l|l|l|l|l|l|}
\hline & \multicolumn{3}{|c|}{ Uji Validitas } & \multicolumn{2}{c|}{ Uji Reliabilitas } \\
\hline \multicolumn{1}{|c|}{ Item } & $\begin{array}{c}\text { Koefisien } \\
\text { Korelasi }\end{array}$ & \multicolumn{1}{|c|}{ Sig. } & Kesimpulan & Cronbach's Alpha & Kesimpulan \\
\hline $\mathrm{X}_{1.1}$ & 0,558 & 0,000 & Valid & 0,845 & Reliabel \\
\hline $\mathrm{X}_{1.2}$ & 0,592 & 0,000 & Valid & 0,844 & Reliabel \\
\hline $\mathrm{X}_{2.1}$ & 0,598 & 0,000 & Valid & 0,843 & Reliabel \\
\hline
\end{tabular}




\begin{tabular}{|c|c|c|c|c|c|}
\hline \multirow[b]{2}{*}{$\mathrm{X}_{2.2}$} & \multicolumn{3}{|c|}{ Uji Validitas } & \multicolumn{2}{|c|}{ Uji Reliabilitas } \\
\hline & 0,382 & 0,000 & Valid & 0,851 & Reliabel \\
\hline $\mathrm{X}_{3.1}$ & 0,527 & 0,000 & Valid & 0,846 & Reliabel \\
\hline$X_{3.2}$ & 0,621 & 0,000 & Valid & 0,843 & Reliabel \\
\hline $\mathrm{X}_{3.3}$ & 0,533 & 0,000 & Valid & 0,846 & Reliabel \\
\hline $\mathrm{X}_{4.1}$ & 0,374 & 0,000 & Valid & 0,852 & Reliabel \\
\hline$X_{4.2}$ & 0,221 & 0,006 & Valid & 0,860 & Reliabel \\
\hline $\mathrm{X}_{5.1}$ & 0,381 & 0,000 & Valid & 0,851 & Reliabel \\
\hline $\mathrm{X}_{5.2}$ & 0,403 & 0,000 & Valid & 0,851 & Reliabel \\
\hline$X_{6.1}$ & 0,701 & 0,000 & Valid & 0,838 & Reliabel \\
\hline$X_{6.2}$ & 0,701 & 0,000 & Valid & 0,837 & Reliabel \\
\hline $\mathrm{X}_{6.3}$ & 0,585 & 0,000 & Valid & 0,845 & Reliabel \\
\hline$X_{6.4}$ & 0,630 & 0,000 & Valid & 0,842 & Reliabel \\
\hline$X_{7.1}$ & 0,552 & 0,000 & Valid & 0,846 & Reliabel \\
\hline $\mathrm{X}_{7.2}$ & 0,510 & 0,000 & Valid & 0,847 & Reliabel \\
\hline $\mathrm{X}_{9}$ & 0,212 & 0,008 & Valid & 0,861 & Reliabel \\
\hline $\mathrm{X}_{10.1}$ & 0,540 & 0,000 & Valid & 0,846 & Reliabel \\
\hline $\mathrm{X}_{10.2}$ & 0,460 & 0,000 & Valid & 0,849 & Reliabel \\
\hline $\mathrm{X}_{10.3}$ & 0,431 & 0,000 & Valid & 0,850 & Reliabel \\
\hline
\end{tabular}

Sumber: Hasil Olah Data SPSS V. 26, 2021

\section{Uji Multikolinearitas}

Tabel 4. Uji Multikolinearitas

\begin{tabular}{|l|l|l|}
\hline Variabel & Tolerance & VIF \\
\hline Kompensasi $\left(\mathrm{X}_{1}\right)$ & 0,610114 & 1,639039 \\
\hline $\begin{array}{l}\text { Keberagaman Pengalaman Kerja } \\
\left(\mathrm{X}_{2}\right)\end{array}$ & 0,698725 & 1,431178 \\
\hline Marketability $\left(\mathrm{X}_{3}\right)$ & 0,473932 & 2,110007 \\
\hline Turnover yang Tinggi $\left(\mathrm{X}_{4}\right)$ & 0,872462 & 1,146181 \\
\hline
\end{tabular}


162 Vania Susanto, Jeremy Everrell, Nany Chandra Marsetio dan Achmad Setyo Hadi

\begin{tabular}{|l|l|l|}
\hline Lingkungan Kerja $\left(\mathrm{X}_{5}\right)$ & 0,763292 & 1,310115 \\
\hline Subjective Norms $\left(\mathrm{X}_{6}\right)$ & 0,532860 & 1,876666 \\
\hline $\begin{array}{l}\text { Kesulitan Memperoleh Sertifikasi } \\
\mathrm{CPA}\left(\mathrm{X}_{7}\right)\end{array}$ & 0,709797 & 1,408854 \\
\hline Travel Berlebihan $\left(\mathrm{X}_{9}\right)$ & 0,830746 & 1,203738 \\
\hline Pengalaman Magang $\left(\mathrm{X}_{10}\right)$ & 0,732683 & 1,364847 \\
\hline
\end{tabular}

Sumber: Hasil Olah Data SPSS V. 26, 2021

Tabel 4 menunjukkan hasil uji multikolinearitas bahwa data yang telah diterima dari responden tidak memiliki gejala multikol dengan dasar penilaian tolerance $>0,1$ dan nilai VIF $<10$.

\section{Pengujian Hipotesis}

Tabel 5. Uji Keseluruhan Model, Uji Koefisien Determinasi, Uji Kelayakan Model

\begin{tabular}{|c|c|c|c|c|c|}
\hline \multicolumn{2}{|c|}{ Uji Keseluruhan Model } & \multicolumn{2}{|c|}{ Uji Koefisien Determinasi } & \multicolumn{2}{|c|}{ Uji Kelayakan Model } \\
\hline-2 Log likelihood & Nilai & $\begin{array}{l}\text { Cox \& Snell } \\
\mathrm{R}^{2}\end{array}$ & $\begin{array}{l}\text { Nagelkerke } \\
\mathrm{R}^{2}\end{array}$ & Chi-square & Sig. \\
\hline $\begin{array}{l}\text { Awal (block number } \\
=0 \text { ) }\end{array}$ & $\begin{array}{l}196,3 \\
82\end{array}$ & \multirow{2}{*}{0,551} & \multirow{2}{*}{0,763} & \multirow{2}{*}{15,007} & \multirow{2}{*}{0,059} \\
\hline $\begin{array}{l}\text { Akhir (block number } \\
=1 \text { ) }\end{array}$ &, $740^{72}$ & & & & \\
\hline
\end{tabular}

Sumber: Hasil Olah Data SPSS V. 26, 2021

Uji Keseluruhan Model

Hasil dari uji keseluruhan model pada Tabel 5 menunjukkan bahwa model yang digunakan fit. Hal ini dapat dilihat dari adanya penurunan nilai -2LL awal sebesar 196,382 menjadi 72,740 pada -2LL akhir. Penurunan sebesar 123,642 terjadi dari tahap awal pada saat variabel independen belum dimasukkan ke dalam model hingga pada tahap kedua atau akhir variabel independen dimasukkan ke dalam model.

Uji Koefisien Determinasi 
Uji koefisien determinasi dengan melihat nilai cox $\mathcal{E}$ snell $\mathrm{R}$ square dan nagelkerke $\mathrm{R}$ square di Tabel 5 menunjukkan nilai cox $\mathcal{E}$ snell $\mathrm{R}$ square diatas $50 \%$ dan nilai dari nagelkerke $\mathrm{R}$ square sebesar $76,3 \%$ yang dapat disimpulkan $76,3 \%$ dari variabel independen dapat menjelaskan variabel dependen dan sisanya 23,6\% dijelaskan oleh variabel lainnya.

Uji Kelayakan Model

Hasil uji kelayakan model di Tabel 5 membuktikan bahwa model yang digunakan layak untuk digunakan pada proses analisis berikutnya dengan signifikansi 0,059 yang ada di atas 0,05 .

Uji Wald

Tabel 6. Uji Wald

\begin{tabular}{|l|l|l|l|}
\hline & B & Sig. & Exp (B) \\
\hline$X_{1}$ & 0,52 & $0,043^{* *}$ & 1,683 \\
\hline$X_{2}$ & 0,316 & 0,219 & 1,372 \\
\hline$X_{3}$ & $-0,127$ & 0,582 & 0,881 \\
\hline$X_{4}$ & $-0,488$ & $0,052^{*}$ & 0,614 \\
\hline$X_{5}$ & $-0,342$ & 0,153 & 0,710 \\
\hline$X_{6}$ & 0,29 & $0,007^{* *}$ & 1,337 \\
\hline$X_{7}$ & $-0,044$ & 0,827 & 0,957 \\
\hline$X_{8}$ & 4,074 & $0,000^{* *}$ & 58,765 \\
\hline$X_{9}$ & $-1,047$ & $0,002^{* *}$ & 0,351 \\
\hline$X_{10}$ & $-0,128$ & 0,501 & 0,880 \\
\hline$X_{11}$ & 1,926 & 0,013 & 6,863 \\
\hline Constant & 0,255 & 0,939 & 1,290 \\
\hline
\end{tabular}

Sumber: Hasil Olah Data SPSS V. 26, 2021

Dari hasil uji wald di Tabel 6 dapat diketahui bahwa hipotesis yang diterima adalah kompensasi $\left(\mathrm{X}_{1}\right)$, turnover tinggi $\left(\mathrm{X}_{4}\right)$, subjective norms $\left(\mathrm{X}_{6}\right)$, rencana mengambil sertifikasi CPA $\left(\mathrm{X}_{8}\right)$ dan travel berlebihan $\left(\mathrm{X}_{9}\right)$. Hipotesis yang diterima berarti setiap variabel tersebut memiliki pengaruh terhadap minat berkarir sebagai akuntan publik. Pengaruh positif didapatkan dari variabel kompensasi, subjective norms, dan rencana mengambil sertifikasi CPA, sedangkan pengaruh negatif yaitu turnover tinggi dan travel berlebihan. Variabel keberagaman pengalaman kerja $\left(\mathrm{X}_{2}\right)$, marketability $\left(\mathrm{X}_{3}\right)$, lingkungan kerja $\left(\mathrm{X}_{5}\right)$, kesulitan memperoleh sertifikasi CPA $\left(\mathrm{X}_{7}\right)$, dan pengalaman magang $\left(\mathrm{X}_{10}\right)$ ditolak yang artinya tidak memiliki pengaruh terhadap niat mahasiswa akuntansi dalam berkarir 
sebagai akuntan publik. Sedangkan jenis kelamin $\left(\mathrm{X}_{11}\right)$ sebagai variabel kontrol memiliki koefisien positif dan signifikan yang menunjukkan bahwa mahasiswa akuntansi yang berjenis kelamin perempuan maupun laki-laki menganggap bahwa kesepuluh variabel independen berpengaruh terhadap pemilihan karir sebagai akuntan publik.

\section{Pembahasan}

Hasil penelitian menunjukkan bahwa kompensasi, norma subjektif serta rencana mengambil sertifikasi CPA dapat meningkatkan probabilitas mahasiswa akuntansi untuk memilih karir sebagai akuntan publik. Profesi akuntan publik menyediakan gaji awal yang tinggi serta kenaikan gaji yang cepat sehingga membuat mahasiswa tertarik untuk berkarir di bidang tersebut. Hal ini konsisten dengan penemuan Omar et al. (2015) dan Sari (2013). Hasil penelitian juga didukung oleh informan yang mengatakan bahwa salah satu faktor yang membentuk keinginan untuk menjadi akuntan publik adalah perkataan dari orang sekitar bahwa akuntan publik memberikan gaji awal yang tinggi serta kenaikan gaji yang cepat, seperti akan mendapatkan gaji sekitar puluhan juta setelah dua sampai tiga tahun bekerja.

Norma subjektif memiliki pengaruh ke pemilihan karir sebagai akuntan publik seperti yang ditemukan oleh Solikhah (2014) dan Dewi \& Budiasih (2017). Pengaruh dari orang-orang di sekitar seperti keluarga, teman, orang terdekat yang sukses, dan dosen menjadi pertimbangan untuk berkarir menjadi akuntan publik karena mereka memberi gambaran yang baik mengenai manfaat apa saja yang bisa didapatkan. Hal ini didukung dengan pernyataan salah satu informan yang mengatakan bahwa saudara-saudara yang bekerja sebagai akuntan publik memberikan gambaran bahwa banyak manfaat yang bisa diperoleh saat bekerja sebagai akuntan public, seperti bisa jalan-jalan, kerja tim yang kompak serta naik jabatan yang cepat.

Rencana mengambil sertifikasi CPA juga meningkatkan kecenderungan dalam pemilihan karir. Hasil ini sejalan dari temuan Wen et al. (2018). Hal menarik yang ditemukan adalah $61,3 \%$ dari total responden memiliki minat untuk mengambil sertifikasi CPA dan berkarir sebagai akuntan publik, padahal yang memiliki minat menjadi akuntan publik adalah $67,1 \%$ dari total responden. Sisa lainnya yang ingin menjadi akuntan publik tetapi tidak memiliki rencana untuk mengambil sertifikasi CPA karena sertifikasi CPA bukan menjadi persyaratan untuk bekerja sebagai akuntan publik di Indonesia.

Turnover yang tinggi dan travel berlebihan menurunkan probabilitas pemilihan karir sebagai akuntan publik. Semakin banyak perkataan dari orang sekitar mengenai tingginya turnover di KAP, mahasiswa semakin tidak tertarik berkarir di bidang tersebut. Hal ini konsisten dengan Wen et al. (2018). Calon karyawan tidak tertarik untuk bekerja di perusahaan yang memiliki turnover yang tinggi. Menurut salah satu informan, turnover yang tinggi ini dapat disebabkan oleh beberapa hal, seperti workload kerja yang sulit, tidak tahan dengan deadline yang diberikan, benefit yang didapatkan tidak sebanding dengan pekerjaan yang dikerjakan atau kohesivitas dalam perusahaan yang rendah.

Sejalan dengan penelitian Wen et al. (2018) dan Nouri et al. (2005) bahwa travel berlebihan yang dijalani jika berprofesi sebagai akuntan publik menurunkan kemungkinan pemilihan karir di bidang tersebut. Mahasiswa akuntansi menganggap profesi tersebut melibatkan frekuensi bepergian yang tinggi saat berkunjung ke klien 
sehingga menyebabkan tekanan untuk diri sendiri, waktu bersama keluarga menjadi berkurang, homesick, dan proses adaptasi yang sulit di tempat baru. Menurut informan, batas wajar bepergian yang berhubungan dengan pekerjaan akuntan publik adalah sekali bepergian berjangka waktu sekitar dua minggu.

Keberagaman pengalaman kerja, marketability, lingkungan kerja, kesulitan memperoleh sertifikasi CPA, serta pengalaman magang tidak berpengaruh terhadap pemilihan karir sebagai akuntan publik. Keberagaman pengalaman kerja yang melibatkan bekerja di industri yang bervariasi dan dapat membantu pengembangan diri tidak menjadi pertimbangan karena pengembangan diri dapat dilakukan dalam prosesi apapun. Konsisten dengan Saputra (2018) yang mengatakan pelatihan profesional tidak memiliki pengaruh terhadap pemilihan karir sebagai akuntan publik. Menurut informan, pengembangan diri juga tidak hanya bisa didapatkan dari bekerja sebagai akuntan publik tetapi bisa didapatkan dari profesi apa pun. Walaupun pengalaman kerja di akuntan publik berguna untuk perkembangan karir ke depan, namun hal tersebut tidak mempengaruhi minat untuk menjadi akuntan publik.

Marketability dapat diartikan sebagai pertimbangan pasar kerja juga tidak berpengaruh untuk pemilihan karir. Hasil ini konsisten dengan penemuan Dary \& Ilyas (2017). Mahasiswa akuntansi tidak merasa jika kemudahan untuk memperoleh posisi yang diinginkan hanya bisa didapatkan jika pernah berprofesi sebagai akuntan publik saja karena untuk mencapai sebuah posisi dalam karir, seseorang tetap harus memiliki skills yang diperlukan. Selain itu, menurut informan untuk meningkatkan prestise di mata masyarakat bisa dicapai dari profesi lainnya.

Lingkungan kerja tidak memiliki pengaruh terhadap pemilihan karir sebagai akuntan publik dan sejalan dengan temuan Asmoro et al. (2015) dan Wen et al. (2018). Lingkungan kerja yang dimaksud di penelitian ini berkaitan dengan lingkungan kerja yang dinamis dan apresiatif. Mahasiswa akuntansi tidak merasa bahwa lingkungan kerja yang dinamis mempengaruhi pemilihan karirnya. Selain itu, menurut informan sebuah apresiasi memang merupakan hal wajar yang wajib didapatkan dalam pekerjaan.

Penelitian ini juga menemukan lebih dari 50\% dari mahasiswa akuntansi yang berminat berkarir menjadi akuntan publik merasa kesulitan untuk memperoleh sertifikasi CPA dengan jangka waktu yang lama dan persyaratan yang banyak. Namun, kesulitan ini tidak mempengaruhi keputusan mereka untuk memilih karir tersebut.

Konsisten dengan Ahmad et al. (2015) dan Maelah et al. (2014) bahwa pengalaman magang bukanlah faktor signifikan yang mempengaruhi pemilihan karir mahasiswa akuntansi. Hal ini dikarenakan menurut informan perusahaan tidak memberikan tugas yang berkaitan dengan akuntansi kepada mahasiswa magang. Pengalaman magang juga tidak memberikan pengetahuan dan keterampilan yang relevan untuk pekerjaan di masa depan. Hal ini dikarenakan tugas yang diberikan saat magang cenderung merupakan tugas yang sederhana, seperti meng-input data, vouching, dan sebagainya. Selain itu, pengalaman yang didapat saat magang masih terhitung sedikit karena jangka waktu yang pendek, sehingga seseorang harus belajar terus menerus untuk mendapatkan pengetahuan dan keterampilan dalam berkarir di masa depan. Selain itu, informan merasa pengalaman magang tidak membuatnya terbiasa dengan tekanan di dunia kerja karena tugas yang dikerjakan hanya berdasarkan arahan dari atasan. 
Hasil penelitian membuktikan penggunaan TPB dalam keputusan pemilihan karir mahasiswa akuntansi. Sikap terhadap perilaku yang dinilai dari pandangan positif akan kompensasi yang tinggi dan pandangan negatif mengenai turnover yang tinggi di KAP, norma subjektif yang dinilai dari pengaruh orang-orang sekitar, serta kontrol perilaku yang dipersepsikan yang dinilai dari kesulitan yang dirasakan dari travel berlebihan mempengaruhi perilaku seseorang untuk memilih karir sebagai akuntan publik. Teori motivasi juga terlihat dalam memotivasi keputusan mahasiswa dalam memilih karirnya dimana mereka akan lebih memilih pekerjaan yang bisa memberikan kepuasan kerja dan adanya pengurang dari ketidakpuasan yang didapatkan dari pekerjaan. Hal ini dapat dilihat dari kompensasi dan subjective norms yang merupakan faktor ekstrinsik yang berfungsi untuk menghindari ketidakpuasan selama bekerja, sedangkan sertifikasi CPA sebagai faktor intrinsik dapat dikatakan sebagai bentuk pencapaian yang merupakan kepuasan bagi seorang individu. Untuk travel berlebihan dan turnover merupakan bentuk dari ketidakpuasan kerja, sehingga dengan adanya faktor tersebut akan mengurangi kepuasan selama bekerja dan membuat individu akan mempertimbangkan untuk keluar atau pindah dari pekerjaan tersebut.

\section{PENUTUP}

Berdasarkan hasil analisis, dapat disimpulkan bahwa kompensasi, subjective norms, dan rencana mengambil sertifikasi CPA berpengaruh positif terhadap pemilihan karir sebagai akuntan publik sedangkan turnover yang tinggi dan travel berlebihan berpengaruh negatif terhadap pemilihan karir mahasiswa akuntansi sebagai akuntan publik. Kemudian keberagaman pengalaman kerja, marketability, lingkungan kerja, kesulitan memperoleh sertifikasi CPA, dan pengalaman magang tidak berpengaruh terhadap pemilihan karir sebagai akuntan publik. Implikasi penting dari penelitian ini adalah sebagai referensi untuk penelitian selanjutnya yang ingin meneliti faktor yang berpengaruh dalam pemilihan karir akuntan publik, untuk penyusunan kurikulum program studi akuntansi dalam mempersiapkan mahasiswa untuk ujian sertifikasi CPA, sebagai bahan interview saat proses rekrutmen di Kantor Akuntan Publik, serta sebagai masukan bagi Institut Akuntan Publik Indonesia untuk melakukan sosialisasi mengenai persyaratan untuk ujian sertifikasi CPA. Keterbatasan penelitian ini adalah beberapa wawancara untuk triangulasi hanya dilakukan melalui pesan singkat karena informan keberatan dengan panggilan telepon sehingga dapat menimbulkan kesalahpahaman akan pertanyaan yang diberikan atau opini yang diperoleh tidak maksimal. Saran untuk penelitian selanjutnya untuk memperluas jumlah sampel penelitian ke luar Pulau Jawa, menambah variabel independen lain untuk mengetahui lebih dalam mengenai penggunaan TPB, menyebarkan langsung kuesioner tanpa melalui pihak ketiga, dan menetapkan kriteria sampel penelitian dengan periode magang yang sama untuk setiap responden, yaitu 6 bulan agar setiap responden memiliki pengalaman yang seimbang dan durasi magang yang lebih lama. 


\section{DAFTAR PUSTAKA}

Ahmed, K., Alam, K. F., \& Alam, M. (1997). An empirical study of factors affecting accounting students' career choice in New Zealand. Accounting Education, 6(4), 325 335.

Ajzen, I. (1991). The theory of planned behavior. Organizational behavior and human decision processes, 50(2), 179-211.

Albert, A., \& Anderson, J. A. (1984). On the existence of maximum likelihood estimates in logistic regression models. Biometrika, 71(1), 1-10.

Albrecht, W. S., \& Sack, R. J. (2000). Accounting education: Charting the course through a perilous future (Vol. 16). Sarasota, FL: American Accounting Association.

Ambari, I. P., \& Ramantha, I. W. (2017). Pertimbangan Pasar Kerja, Pengakuan Profesional, Nilai-Nilai Sosial, Lingkungan Kerja, Personalitas Pemilihan Karir sebagai Akuntan Publik. E-Jurnal Akuntansi Universitas Udayana, 18(1).

Bagley, P. L., Dalton, D., \& Ortegren, M. (2012). The factors that affect accountants' decisions to seek careers with big 4 versus non-big 4 accounting firms. Accounting Horizons, 26(2), 239-264.

Crisostomo, D. T. (2015). STUDENTS' PERCEPTION OF THE ACCOUNTING INTERNSHIP PROGRAM. Academy of Educational Leadership Journal, 19(1), 167.

Dary, A. W., \& Ilyas, F. (2017). Pengaruh Gender, Penghargaan Finansial dan Pertimbangan Pasar Kerja Terhadap Minat Mahasiswa Akuntansi Untuk Berkarir Menjadi Akuntan Publik dan Non Akuntan Publik. Jurnal Akuntansi, 7(1), 51-60.

Denzin, N. K. (1970). The Research Act in Sociology. Chicago: Aldine.

Dewi, N. K. D. K., \& Budiasih, I. G. A. N. (2017). Pengaruh Kecerdasan Emosional, Norma Subjektif, dan Kontrol Perilaku pada Minat Berkarir Mahasiswa Pendidikan Profesi Akuntansi. E-Jurnal Akuntansi Universitas Udayana, 20.

Edward, B. J., \& Halim, H. (2008). Undergraduate internships in accounting: What and how do Singapore interns learn from experience? Accounting Education: an international journal, 17(2), 151-172.

Gore Jr, P. A., \& Leuwerke, W. C. (2000). Predicting occupational considerations: A comparison of self-efficacy beliefs, outcome expectations, and person-environment congruence. Journal of Career Assessment, 8(3), 237-250.

Herzberg, F. M., \& Mausner, B. (1959). B. \& snyderman, b.(1959). The motivation to work, 2, 49-58.

Herzberg, F. I. (1966). Work and the Nature of Man.

Herzberg, F. (2003). One more time, how do you motivate workers. Harvard Business Review, 1, 87-96.

Jain, R., \& Kaur, S. (2014). Impact of work environment on job satisfaction. International Journal of Scientific and Research Publications, 4(1), 1-8.

Law, P. K. (2010). A theory of reasoned action model of accounting students' career choice in public accounting practices in the post-Enron. Journal of Applied Accounting Research.

Lukman, H., \& Winata, S. (2017). Pemilihan Karir Sebagai Akuntan Publik Bagi Mahasiswa Perguruan Tinggi Swasta Dengan Pendekatan Theory Of Planned Behaviour. Jurnal Akuntansi, 21(2), 208-218. 
168 Vania Susanto, Jeremy Everrell, Nany Chandra Marsetio dan Achmad Setyo Hadi

Maelah, R., Mohamed, Z. M., Ramli, R., \& Aman, A. (2014). Internship for accounting undergraduates: comparative insights from stakeholders. Education+ Training.

Martin, D. R., \& Wilkerson Jr, J. E. (2006). An examination of the impact of accounting internships. The Accounting Educators' Journal, 16.

Merdekawati, D. P., \& Sulistyawati, A. I. (2011). Faktor-faktor yang mempengaruhi pemilihan karir akuntan publik dan non akuntan publik. Jurnal Ilmiah Aset, 13(1), 9-19.

Nouri, H., Parker, R. J., \& Sumanta, S. (2005). Students' perceptions of work in public accounting and employment preferences. Accounting Education, 14(3), 293-311.

Nouri, H., \& Parker, R. J. (2013). Career growth opportunities and employee turnover intentions in public accounting firms. The British accounting review, 45(2), 138148.

Omar, M. K., Zakaria, A., Ismail, S., Sin, J. S. L., \& Selvakumar, V. (2015). Job selection preferences of accounting students in Malaysian private universities. Procedia Economics and Finance, 31, 91-100.

Otoritas Jasa Keuangan. (2021). Perusahaan Fintech Lending Berizin dan Terdaftar di OJK [Data File]. Retrieved April 21, 2021, from https://www.ojk.go.id/id/kanal/iknb/financialtechnology/Documents/Penyelenggara\%20Fintech\%20Lending\%20Terdaftar\%2 Odan\%20Berizin\%20di\%20OJK\%20per\%2016\%20Maret\%202021.pdf

Polit, D.F., Beck, C.T. and Hungler, B.P. (2001), Essentials of Nursing Research: Methods, Appraisal and Utilization. 5th Ed., Philadelphia: Lippincott Williams \& Wilkins

Saputra, A. J. (2018). Pengaruh Persepsi Mahasiswa Akan Minat, Motivasi, Pelatihan Profesional, Gender Dan Lingkungan Pekerjaan Terhadap Pilihan Karir Akuntan Publik Dan Non Publik. Jurnal Riset Akuntansi Mercu Buana, 4(2), 126-135.

Sari, M. (2013). Faktor-faktor yang mempengaruhi pemilihan karir menjadi akuntan publik oleh mahasiswa Departemen Akuntansi Fakultas Ekonomi UMSU Medan. Jurnal Riset Akuntansi dan Bisnis, 13(2).

Sun, L. Y., \& Zhang, T. (2016). Empirical study on accounting graduates training mode in China technical and vocational schools: survey on graduates' employment. Communication of Finance and Accounting, 7(699), 55-58.

Solikhah, B. (2014). An application of Theory of Planned Behavior towards CPA career in Indonesia. Procedia-Social and Behavioral Sciences, 164, 397-402.

Sugiyono (2017). Metode Penelitian Kualitatif: Untuk penelitian yang bersifat: eksploratif, enterpretif, interaktif, dan konstruktif. Bandung: Alfabeta.

Taylor, S. L., \& Cosenza, R. M. (1998). Reducing turnover in public accounting firms: an internal marketing strategy. Journal of Professional Services Marketing, 17(2), 135 157.

Wen, L., Yang, H. C., Bu, D., Diers, L., \& Wang, H. (2018). Public accounting vs private accounting, career choice of accounting students in China. Journal of Accounting in Emerging Economies, 8(1), 124-140. 
